\title{
BENDROSIOS PRAKTIKOS SLAUGOS STUDIJŲ STUDENTŲ AKTYVAUS İSITRAUKIMO İ SAVARANKIŠKŲ DARBŲ RENGIMĄ PRIELAIDOS
}

\author{
Dalè Smaidžiūnienė, Vilma Rastenienė \\ Kauno kolegijos Medicinos fakultetas
}

Raktažodžiai: savarankiškas darbas, slaugos studijos, edukaciniai ir organizaciniai savarankiškų darbų atlikimo aspektai.

\begin{abstract}
Santrauka
Pagrindinis mokymo institucijų, rengiančių slaugos specialistus uždavinys - rengti aukštos kvalifikacijos slaugos specialistus, atitinkančius Europos Sąjungos ir šalies bei regiono darbo rinkos poreikius. Šiuolaikinio mokymo proceso tikslas yra gebejjimas savarankiškai ieškoti žinių, jas kritiškai vertinti, sisteminti, gebèti taikyti profesineje veikloje. Tyrimo tikslas - atskleisti bendrosios praktikos slaugos studijų programos studentų požiūrị i t savarankiškų darbų edukacinius, organizacinius aspektus bei išryškinti veiksnius, igalinančius studentus aktyviai įsitraukti i savarankiškų darbų rengimą, siekiant reikiamų profesinių žinių. Tyrimas atskleidè edukacinius aspektus, motyvuojančius studentus aktyviai įsitraukti ị savarankiškų darbų rengimą: savarankiško darbo sąsajos su būsima profesija, parama studentui, savarankiškų darbų užduočių integracija tarpdisciplininiu požiūriu, pagalba pasirenkant savarankiško darbo temą, lankstus dèstytojo požiūris ị savarankiško darbo temos, grupès pasirinkimą, grịžtamojo ryšio suteikimas. Dėstytojai studijų eigoje turètų didesnị dẻmesị skirti savarankiško darbo atlikimo eigai, komunikacijai su studentu, studentų grupėmis, atliekant grupini savarankišką darbą, bendradarbiauti sprendžiant studentams aktualius klausimus.
\end{abstract}

\section{İvadas}

Slaugytojo profesija Europos valstybėse ir Lietuvoje per pastaruosius kelis dešimtmečius patyrė pokyčius specialistų rengimo, slaugos praktikos, profesinès reguliacijos ir judejimo laisvès srityse, teikiant slaugytojo veiklai autonomiškumo, priskiriant atsakomybę už sergamumo ir mirtingumo mažinimą, sveikatos ugdymą ir palaikymą, mokslo ir praktikos įrodymais grịstų slaugos profesinių sprendimų priemimą. Slaugos specialistai teikia ne tik ivvairiapuses bendrosios praktikos slaugos paslaugas, bet ir sveikatos mokymo paslaugas pacientui bei jo šeimai. Sveikatos priežiūros sistemoje aktualiais tampa pokyčių ir lyderystès aspektai, kurie yra glaudžiai susiję su grupès dinamikos ir komandos procesu, reikalauja novatoriškumo, lyderio charizmos, intelektinès stimuliacijos, tobulinti klinikinès priežiūros procesų valdymą, kuris lemia kokybiškas sveikatos priežiūros paslaugas.

Šiandieną tradicinę mokymo(si) sampratą aukštosiose mokyklose keičia šiuolaikinè - konstruktyvistinè mokymosi paradigma, apibūdinanti mokymąsi kaip procesą, apimantị studento mąstymo, jausmų, suvokimo bei elgesio kokybinius pokyčius ir išryškinanti jo gebejjimą matyti, patirti ir suprasti realiame pasaulyje vykstančius procesus, galimybę pačiam kurti individualų žinojimą, mąstyti ir vertinti savo asmeninį augimą [2]. Šiuolaikinio mokymo proceso tikslas yra ne žinių kaupimas, o gebejjimas savarankiškai ieškoti žinių, jas kritiškai vertinti, sisteminti ir vartoti kasdieninejje veikloje. Šiems gebejimams ugdyti svarbiausiu metodu tampa savarankiškas darbas [6].

Lietuvos aukštojo mokslo institucijose parengiant ir igyvendinant Europos kreditu kaupimo ir perkèlimo nacionalinę koncepciją yra pradèta taikyti „Tuning Educational Structures in Europe" projekto itvirtinta ECTS metodika. ECTS yra ị besimokantiji orientuota sistema, nes ji studijų programų kūrimo ir vykdymo procese padeda institucijoms akcentuoti besimokančiojo poreikius ir lūkesčius. I besimokantiji orientuotos studijos reikalauja, kad studijuojantysis atsidurtų studijų programų kūrimo ir vykdymo proceso centre, atliktų savarankiškas užduotis ir suteikia jam daugiau galimybių rinktis studijų turinị, būdą, trukmę bei jų vietą [7]. Ivairiose mokslo institucijose bei studijų srityse/kryptyse mokymo(si) veiklos gali skirtis, tačiau viena iš veikų, kurios reikia sèkmingam edukacinio komponento baigimui, yra paties studento savarankiškas indèlis, siekiant pasirinkto tikslo.

Savarankiškas darbas studijų procese yra siektinas tiks- 
las, darbo forma ir mokymosi metodas [8]. Savarankiškas darbas padeda pasiekti žinių, mokẻjimų ir ịūdžių lygị, kuris yra būtinas konkrečiai užduočiai atlikti, ugdo gebejjimą vertinti, analizuoti, apibendrinti teorinę medžiagą, pateikti išvadas, ugdo savarankiško darbo ịūdžius, kūrybiškumą, saviraišką, ugdo bendrąsias ir specialiąsias kompetencijas [4]. Savarankiškas darbas padeda lavinti kritinį, analitinį, refleksyvuji mąstymą, plètoti protavimo autonomiją, padeda išsiugdyti gebejjimą suvokti ir susidoroti su kompleksinemis problemomis, adekvačiai ịvertinti situacijas bei imtis tinkamų sprendimų [11].

ECTS skatina programas sudaryti pagristai, realiai, numatant studentų laiko sąnaudas studijų siekiniams pasiekti [7]. Studijuojant slaugą, svarbiausia yra išmokti praktinių igūdžių, tačiau, kadangi medicinoje nuolat viskas keičiasi, labai svarbu ir išmokti ieškoti informacijos, susijusios su pasirinkta profesija, gebėti šią informaciją analizuoti, sisteminti, taikyti naujai igytas žinias slaugos praktikoje. Savarankiškas darbas lavina šiuos ịgūdžius.

ECTS suteikia mokymo institucijoms laisvę kuriant programas, bet kartu skatina siekti kokybiško studijų organizavimo [7]. Studentų savarankiško darbo kokybės gerinimo priemonès: aktualizuoti studentų savarankiškų darbų užduotis, numatyti studijų profesionalizaciją ugdančias užduotis ar jų komponentes (grupinio darbo, probleminio mokymo, projektinio darbo ir pan.). taip pat ir interaktyvias studijų užduotis, savarankiško darbo užduočių reguliarus atnaujinimas (kas 2-3 m.), skatinti studentų savarankiško darbo savęs įsivertinimą, diferencijuoti savarankiško darbo užduotis (referatai, analitiniai darbai, tyrimai, projektai ir kt.), diferencijuoti savarankiško darbo užduotis atsižvelgiant i studentų išsilavinimo įvairovę, skatinti, kad savarankiški darbai būtų aptariami seminaruose, pratybose ir t.t., aukštesnèse studijų pakopose labiau individualizuoti savarankiško darbo užduotis [4].

Be abejonès, informacijos, reikalingos savarankiškam darbui atlikti, paieška užima daug studentų laiko, todèl dèstytojo pareiga būtų apskaičiuoti galimas laiko sąnaudas ir tinkamai pateikti savarankiško darbo užduotis. Slaugos studentams pateikiami savarankiški darbai turi atitikti studijų programos tikslus bei padèti pasiekti slaugytojo kompetencijas.

Slaugos studijų savarankiško darbo tikslai galètų būti formuojami, kaip ir kitose studijų kryptyse, pagal studiju trukmę, kuo ilgiau studijuojama, tuo sudetingesni savarankiško darbo tikslai. Pvz.: pirmame kurse siekiama pagilinti dalyko žinias, skatinti gilintis ị kai kuriuos studijuojamo dalyko klausimus, ugdyti gebejimą naudotis informacijos šaltiniais, formuoti surinktų duomenų palyginimo igūdžius, formuoti medžiagos apibendrinimo ir išvadų teiki- mo ịgūdžius, o trečiame kurse siekiama formuoti gebèjimą ivvertinti ir išskirti teigiamas, neigiamas ir kitas nagrinèjamos temos ypatybes, formuoti apibendrinimo, analizès, vertinimo ir išvadų teikimo igūdžius, pagilinti dalyko žinias, formuoti aprašomo objekto dalykinio turinio analizès igūdžius, pateikiant vertinimus ir apibendrinančias išvadas, formuoti ịvertinimo gebejjimus, gilinantis i nagrinejjamos temos ypatumus, formuoti analizès, vertinimo ir modeliavimo igūdžius [4]. Studentų atliekamas praktinis savarankiškas darbas turètu remtis kuo ịvairesniais objektyviais informacijos šaltiniais. Toks savarankiškas darbas praktiškai gali būti tapatus probleminiam mokymuisi, kuris vyksta kritinio ir kūrybinio mąstymo dèka [8].

Savarankiško studijavimo organizavimas kelia daug klausimų ir diskusijų dėstytojams: kaip pateikti savarankišką darbą taip, kad studentai pasiektų studijų tikslus, kaip paskaičiuoti savarankiško darbo atlikimo laiko sąnaudas, kaip sudominti studentus ir padèti jiems aktyviai ịsitraukti ị savarankiškas studijas, kaip padaryti taip, kad užduotys nebūtų vienodos, bet būtų ịdomios ir naudingos, kaip pasiekti gerą savarankiškų darbų kokybę bei kitus klausimus. Lietuvoje šias temas nagrinėja V. Žydžiūnaitė, M. Teresevičienė, G. Gedvilienè, A. Pečiūrienè, D. Bulvienè ir kt. autoriai.

Dažnai dèstytojai pateikia grupines savarankiško darbo užduotis. Savarankiškos užduoties atlikimas grupejje - tai savo vaidmens atlikimas ir pasidalijimas atsakomybe su kitais studentais, tačiau studentai nelinkę įsigalinti atsakomybei už laiko valdymą ir numatytų taisyklių laikymąsi, todèl dèstytojas turi sumotyvuoti studentus, atlikti stebėseną, kontrolę, teikti pagalbą, konsultacijas. Jei darbas grupinis būtina išlaikyti vaidmenų lygiavertiškumo balansą [12].

Vertinant studento darbo krūvị sunkiausia apskaičiuoti savarankiško darbo kiekị, kuris labai priklauso nuo konkretaus dalyko ir jo problematikos sudetingumo. Laikas būtinas efektyviam mokymuisi kiekvienam studentui yra individualus ir priklauso nuo daugelio veiksnių: studento gabumų, pasiruošimo ir motyvacijos, turimų žinių, mokymo kokybès, suteikiamų patarimų rekomendacijų ir pan. Literatūroje išskiriamos kontrolès formos atliekant savarankiško darbo užduotis: dėstytojo kontrolè, studentų tarpusavio kontrolè bei savikontrolė [3].

Kalbant apie savarankiško mokymosi poveiki bei tiesioginę naudą besimokantiems, reikètų pabrèžti, kad nauda yra: pagerèję mokymosi rezultatai, didesnè besimokančiojo motyvacija ir pasitikejjimas, didesnis studentų supratimas apie galimus apribojimus ir gebejimas juos valdyti, o grupinis savarankiškas darbas skatina socialinį besimokančiųų įsitraukimą i užduoties atlikimą. Naudingi studijų procesui išoriniai ir vidiniai veiksniai: išoriniai veiksniai apima stipraus ryšio tarp mokytojų ir besimokančiųjų kū- 
rimą, kuris sudaro palankias sąlygas individualiam kompetencijų igijimui ir tobulinimui, o vidiniai veiksniai yra pažinimo ịgūdžių, tokių kaip dèmesio, atminties, problemų

1 lentelė Bendrosios praktikos slaugos studijų programos studentų nuomonė apie savarankiškiems darbams keliamus reikalavimus

\begin{tabular}{|c|c|c|c|}
\hline Kategorijos & $\begin{array}{l}\text { Subkate- } \\
\text { gorijos }\end{array}$ & $\begin{array}{l}\text { Autentiški studentų } \\
\text { pasisakymai }\end{array}$ & $\begin{array}{c}\text { Kartotinių } \\
\text { skaičius }\end{array}$ \\
\hline \multirow[t]{4}{*}{$\begin{array}{l}\text { Reikalavimai } \\
\text { apimčiai ir } \\
\text { turiniui }\end{array}$} & $\begin{array}{l}\text { Aiškūs } \\
\text { reikala- } \\
\text { vimai }\end{array}$ & $\begin{array}{l}\text { „Dauguma dėstytojų pateikia aiškius } \\
\text { reikalavimus savarankiškam darbui“ } \\
\text { „,...nurodo naudoti ne mažiau nei } \\
\text { penkis literatūros šaltinius, neleidžia } \\
\text { naudoti internetinių lietuvių kalba...“ }\end{array}$ & 78 \\
\hline & $\begin{array}{l}\text { Neaiškūs/ } \\
\text { nevienodi } \\
\text { reikala- } \\
\text { vimai ir } \\
\text { vertinimas }\end{array}$ & $\begin{array}{l}\text { „Ne visi dèstytojai išaiškina } \\
\text { ko iš tiesų reikalauja, dėstytojų } \\
\text { reikalavimai labai skiriasi“ } \\
\text { „...nuo dèstytojo priklauso, dalis } \\
\text { dèstytojų reikalavimų nepateikia“ } \\
\text { “...griežtos struktūros nereikalauja, } \\
\text { tačiau po to griežtai vertina“ } \\
\text { „pirmam kurse nereikèjo dèt } \\
\text { literatūros šaltinių slaugos plane, } \\
\text { trečiam kurse nevertino, kai ju } \\
\text { nebuvo, reikèjo perdaryt““ }\end{array}$ & 38 \\
\hline & $\begin{array}{l}\text { Per } \\
\text { sudėtinga } \\
\text { užduotis }\end{array}$ & $\begin{array}{l}\text { „Vieni dèstytojai užduoda lengvai } \\
\text { ir aiškiai suprantamus dalykus, kiti } \\
\text { - užduoda tokius, su kuriais sunku } \\
\text { susidoroti“ } \\
\text { "Yra tekę prašyti dėstytojo pakeisti } \\
\text { užduotị, nes neradau literatūros ir ji } \\
\text { buvo man per sunki“ }\end{array}$ & 9 \\
\hline & $\begin{array}{l}\text { Literatūra } \\
\text { ir literatū- } \\
\text { ros šaltiniụ } \\
\text { skaičius }\end{array}$ & $\begin{array}{l}\text { “...dauguma: } 12 \text { lapų, } 3-5 \text { šaltiniai, } \\
\text { šaltiniai ne internetiniai, g.b. } 1 \\
\text { internetinis" } \\
\text { "Pirmame kurse literatūros } \\
\text { reikalavimai nedideli, bet antrame } \\
\text { ir trečiame jie vis griežtėja: } 3 \text { kurse } \\
\text { pareikalavo skaidrèse ir tekste sudėti } \\
\text { šaltinius" } \\
\text { "Naudojuosi daugeliu literatūros } \\
\text { šaltinių, nes viename sunku rasti } \\
\text { reikiamos medžiagos" } \\
\text { "Kai kurie dėstytojai reikalauja ne } \\
\text { kiekybės, bet kokybės, neleidžia } \\
\text { naudoti lietuviškų internetinių } \\
\text { šaltinių, kurie yra nepatikimi” }\end{array}$ & 35 \\
\hline $\begin{array}{l}\text { Profesiniai } \\
\text { reikalavimai }\end{array}$ & $\begin{array}{l}\text { Darbas } \\
\text { turi būti } \\
\text { siejamas } \\
\text { su būsima } \\
\text { profesija }\end{array}$ & $\begin{array}{l}\text { "dauguma dėstytojų reikalauja } \\
\text { slaugos" } \\
\text { "kai kurie dèstytojai nereikalauja } \\
\text { slaugos < ..> rašai ir net pats } \\
\text { nesupranti ką, ir kam rašai" } \\
\text { " nematau prasmès daryt } \\
\text { nereikalingus darbus" }\end{array}$ & 50 \\
\hline Plagiatai & & $\begin{array}{l}\text { "sužinojom jau pirmam kurse sąvoką } \\
\text { plagiatas, tačiau, kas tai yra iš tikrųju } \\
\text { supratom tik trečiame" }\end{array}$ & 3 \\
\hline
\end{tabular}

sprendimo, metakognityvinių igūdžių, susijusių su mokymosi proceso suvokimu, afektinių ịūdžių, susijusių su jausmais ir emocijomis tobulinimas [1].

Užsienio literatūroje ieškant informacijos apie savarankiško studijavimo organizavimą pastebejome, kad mokymo institucijos skiria daug demesio padedant studentui įsitraukti i studijas, taip pat mokymosi institucijų tinklalapiuose dažnai pateikiama informacija, nuorodos, videomedžiaga ar kita pagalba, padedanti studentui savarankiškai studijuoti. Studentams reikalinga pagalba ne tik atliekant konkrečias užduotis, o apskritai pradedant studijas jiems reikia pristatyti studiju strategijas, nes besimokydami studentai dažniausiai ( 83,6 proc.) pasirenka neefektyvias mokymosi strategijas, tokias kaip teksto skaitymas ir retai naudoja efektyvias strategijas - praktinio pritaikymo galimybes (42,9 proc.), studijuoti kartu su kitais studentais $(26,5$ proc.) ar praktiškai prisiminti bei pasitikrinti savo žinias (10,7 proc.) $[5,10]$.

Kaip igalinti studentus noreti savarankiškai studijuoti, gauti optimalią naudą iš savarankiškų darbų? JAV atlikti tyrimai parode, kad reikia leisti studentams savarankiškai pasirinkti savo mokymosi veiklą ir patiems nusistatyti savo mokymosi tikslus, anot JAV mokslininkų, taip pat svarbu, kad mokymo institucijoje būtų vieninga ugdymo strategija, kuri parodo studentams savarankiško mokymosi galimybes ir naują požiūrị i mokymąsi [9].

Darbo tikslas - atskleisti bendrosios praktikos slaugos studijų programos studentų požiūrị i savarankiškų darbų edukacinius, organizacinius aspektus bei išryškinti veiksnius, igalinančius studentus aktyviai įsitraukti ị savarankiškų darbų rengimą, siekiant reikiamų profesinių žinių.

\section{Tyrimo metodai ir kontingentas}

Mokslinès literatūros analizè, grupinès diskusijos metodas, anketinè apklausa, kokybinè turinio analizè.

Pirmą tiriamųjų grupę sudare 82 pirmo kurso slaugos studijų studentai, penktadalis šių studentų turejo studijų patirties kitose srityse. Antrą tiriamujų grupę sudarè 12 trečio kurso studentų, vienas jų turejo studijų patirties kitose studijų kryptyse. Pirmo kurso studentams buvo pateikta anketa, o trečio kurso studentams buvo pritaikytas grupinès diskusijos metodas. 


\section{Tyrimo rezultatai}

Tyrimo metu siekème išsiaiškinti, kokius reikalavimus studentų požiūriu savarankiškiems darbams kelia dèstytojai? Tyrimas atskleidè, kad dažniausiai keliami reikalavimai yra savarankiškų darbų apimčiai ir turiniui. Remiantis tyrimo duomenimis, galima teigti, kad ne visuomet dèstytojai, pateikdami savarankiško darbo reikalavimus, reikalauja pateikti naudotos literatūros sąrašą tekste arba/ir savarankiško darbo pabaigoje - ,pirmame kurse nereikejo deti literatūros šaltinių slaugos plane" bei ne visi dèstytojai reikalauja sieti savarankišką darbą su slaugytojo profesija. Studentai nepalankiai vertina savarankiško darbo užduotis, jeigu savarankiškas darbas nèra siejamas su slaugytojo profesija „...rašai ir net pats nesupranti ką, ir kam rašai“, jei dèstytojas ,griežtos struktūros nereikalauja, tačiau po to griežtai vertina“", jei užduotis, studento požiūriu, yra per sunki: ..., ,sunku susidoroti“, „,neradau literatūros“. Bendrosios praktikos slaugos studijų programos studentų nuomonè apie savarankiškiems darbams keliamus reikalavimus pateikiama 1 lenteleje.

Tyrimu siekėme išsiaiškinti, kaip bendrosios praktikos slaugos studijų programos studentai vertina studentams pateikiamų darbų tikslingumą? Didžioji dalis studentų teigiamai vertina savarankiškus darbus, kaip mokymo/si metodą, kadangi savarankiški darbai ,padeda ịsigilinti ị dalyką ir juo labiau pasidomèti“. Studentai ịžvelgia savarankiškų darbų tiesioginę naudą igyjant papildomas bendrąsias ir profesines žinias bei igūdžius, teigia, jog savarankiški darbai skatina domètis naujovèmis, ugdo kūrybiškumą. Tačiau jei savarankišką darbą studentas atlieka nesąžiningai arba atmestinai, tuomet šis darbas, anot studentų, ,...darbas lygus nuliui“. Respondentų nuomonė apie savarankiškų darbų rengimo tikslingumą atsispindi 2 lentelèje.

Studijų dalykų savarankiško darbo užduočių skaičius paprastai turi būti lygus n-1, kur n yra studijų dalyko kreditų skaičius [4]. Studijų procese studentai pažymi, kad yra apkrauti didelio savarankiškų darbų skaičiaus, todèl dali savarankiškų darbų dèstytojai galètų apjungti, jei tai būtų įmanoma tarpdisciplininiu požiūriu. Respondentams buvo užduotas klausimas apie tarpdisciplininių ryšių užtikrinimą, atliekant savarankiškus darbus, studijų procese. Visi respondentai teige, kad neatliko nei vieno darbo, apimančio 2 dalykus: "taip turèjo būti su informatika, bet dèl nepaaiškinamo dèstytojos užsispyrimo neleido su profesija susijusių dalykų suformuoti“, „,mums neįdomu rašyti apie traktorius”, „farmakologiją gal reiktų susieti su terapija, o pasirenkamų dalykų darbus ir informatiką susieti su būsi-
2 lentelė Bendrosios praktikos slaugos studijų programos studentų nuomonė apie savarankiškų darbų rašymo tikslingumą

\begin{tabular}{|c|c|c|c|}
\hline $\begin{array}{l}\text { Katego- } \\
\text { rijos }\end{array}$ & $\begin{array}{l}\text { Subkate- } \\
\text { gorijos }\end{array}$ & $\begin{array}{c}\text { Autentiški studentų } \\
\text { pasisakymai }\end{array}$ & $\begin{array}{c}\text { Kartotinių } \\
\text { skaičius }\end{array}$ \\
\hline $\begin{array}{l}\text { Gaunama } \\
\text { žinių ir } \\
\text { igūdžių }\end{array}$ & $\begin{array}{l}\text { Savarankiš- } \\
\text { kumo ịgūdžiai }\end{array}$ & $\begin{array}{l}\text { "Savarankišką darbą rašau dèl naujų } \\
\text { žinių ir ịgūdžių ịijimo, padeda tapti } \\
\text { savarankiškiems" } \\
\text { "Padeda ịsigilinti ị dalyką ir juo } \\
\text { labiau pasidomèti" }\end{array}$ & 78 \\
\hline $\begin{array}{l}\text { Naujos } \\
\text { idèjos }\end{array}$ & $\begin{array}{l}\text { Problemų } \\
\text { sprendimas } \\
\text { Nauja } \\
\text { informacija }\end{array}$ & $\begin{array}{l}\text { "Atrandama naujų idėjų sprendžiant } \\
\text { problemas, galimybė išsakyti savo } \\
\text { požiūrị" } \\
\text { "Esi priverstas ieškoti, domėtis nauja } \\
\text { informacija" }\end{array}$ & 45 \\
\hline $\begin{array}{l}\text { Profesinè } \\
\text { nauda }\end{array}$ & $\begin{array}{l}\text { Literatūros } \\
\text { analizės } \\
\text { patirtis }\end{array}$ & $\begin{array}{l}\text { "Padeda plačiau analizuoti literatūrą, } \\
\text { kurią galima pritaikyti bendraujant } \\
\text { su pacientu" }\end{array}$ & 12 \\
\hline $\begin{array}{l}\text { Betikslis } \\
\text { darbas }\end{array}$ & & $\begin{array}{l}\text { "Jei tą darbą padarei sąžiningai, } \\
\text { tai naudos visada yra, bet jei } \\
\text { nusikopinai, tai tas darbas lygus } \\
\text { nuliui"“ } \\
\text { "Man jie daug naudos neduoda"" }\end{array}$ & 10 \\
\hline
\end{tabular}

ma profesija".

Darbo susiejimas su būsima profesija atsispindi studentų pasisakymuose: trys dešimtadaliai pirmakursių $(\mathrm{N}=$ 82) studentų (32,9 proc.) įžvelgia, jog savarankiški darbai dažnai gali būti praktiškai pritaikomi slaugos praktikoje, trečiakursiai savarankiškus darbus vertino palankiau: visi (100 proc.) teige, kad savarankiškus darbus galima pritaikyti praktikoje, anot studentų ,nebūtinai savo atliktą darbą gali pritaikyti, gali pasinaudot kitų surinkta informacija ir pritaikyti“"(1 pav.).

Dauguma pirmakursių ir visi trečio kurso studentai pageidavo, kad savarankiškas darbas būtų siejamas su pasirinkta profesija.

Studentams pateiktas klausimas - kas sudomina ir motyvuoja juos rašyti savarankiškus darbus? Iš studentų pasisakymų galima išskirti šiuos dalykus, kurie sudomina studentus: „idomi darbo tema“, „kai pats studentas pasirenka savarankiško darbo temą“, noras gauti gerą pažymị, siekis neprarasti finansuojamos studijų vietos, matoma nauda ir

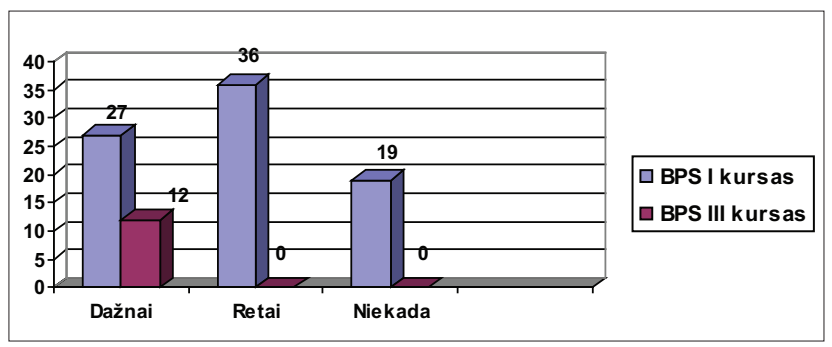

1 pav. Bendrosios praktikos slaugos studentų nuomonė apie savarankiškų darbų pritaikymą slaugos praktikoje 
noras ịgyti naujų žinių studijuojamo dalyko srityje. Taip pat studentus motyvuoja tai, jei parašomas puikus savarankiškas darbas ir pristatymo metu susidomèję klauso ir bendrakursiai: „motyvuoja kai jauti, kad padarei tikrai gerai, smagu kai kitiems smagu klausyti". Studentams tampa neịdomu jei: neįdomi ar per sunki tema, dèstytojas paskiria temą ir esant reikalui neleidžia pasikeisti, mažai žinai apie tą dalyką (su profesija mažai siejasi).

Slauga ne visuomet yra konkretus darbas, ypač pradedant dirbti ši darbą, sunku dirbti su pacientais, kurie visada skundžiasi, dažnai yra nepatenkinti ar kuriems pastoviai ką nors skauda. Dažnai slaugytojas turi kūrybingai žvelgti ị konkrečią situaciją ir rasti individualų sprendimą kiekvienam pacientui. Tyrimo metu bandème išsiaiškinti, kas skatina studentų kūrybiškumą, rašant savarankiškus darbus. Iš studentų pasisakymų galima daryti prielaidą, kad studentams sunku žvelgti kūrybiškai, retas kuris geba pats ką nors įdomaus pasiūlyti ar pasirinkti. Studentams reikalinga dėstytojo parama šioje srityje, studentams trūksta kūrybingumo pasirenkant temą bei pristatant savarankiškus darbus „sunku pasirinkti temą < _..> mes nemokam pateikt, apipavidalint darbų". Anot studentų, kūrybingumą/kūrybingumo stoką veikia: laikas, kompiuteriniai igūdžiai, dėstytojo reikalavimai. Tačiau kai kurie tyrimo dalyviai teigè, kad „trūksta kūrybingumo iš dėstytojų pusès parenkant užduotis, kai kurie dèstytojai duoda atmestinai“, ,....prievartinis studentų įtraukimas ypač jaučiamas 1 kurse”.

Tyrimo metu išryškejjo studentų patirtys, susiję su lankstumu užduodant savarankiškus darbus: „kai kurie dėstytojai žiūri lanksčiai, bet dalis neleidžia pakeisti temos, pasirinkti grupès narius, rašyti savarankišką darbą grupèje ar vienam", daugumos tiriamujų nuomone, ,gerai būtų pačiam rinktis temą, bet, kad gaires duotų dèstytojas".

Studentų nuomone, daugeliu atvejų, jei studentai kreipiasi i dèstytoją „dèstytojai suteikia pagalbą, nurodo dažniausiai atliekamas savarankiškų darbų klaidas“, tačiau ,dauguma stengiasi individualiai nesikreipti i dès-

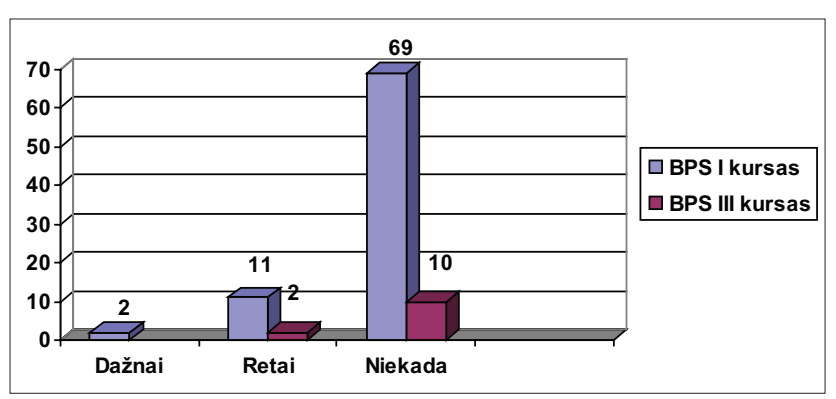

2 pav. Bendrosios praktikos slaugos studijų programos studentų nuomonè apie nesąžiningai atliktus savarankiškus darbus tytoją, nes buvo atvejų kai nepadejo rasti literatūros".

Kaip studentai vertina savo atliktus savarankiškus darbus: didžioji dalis pirmo kurso studentų teigiamai vertina dèstytojo įvertinimą - ,dèstytojo įvertinimas dažnai sutampa su mano įsivertinimu“. Diskusijos metu dauguma trečio kurso studentų venge kalbeti šia tema, tačiau keletas studentų teige, kad „kartais jaučiamès neịvertinti, bet bijom prašyti dèstytojo pakelti pažymi”, tai parodo, kad dažniausiai trūksta bendradarbiavimo, diskusijų ir kontakto su dèstytoju. Viena studente papasakojo atveji, kai dėstytoja prašè dar padirbèti prie darbo, o vèliau ,pamiršo ir nepakèlè pažymio taip ir likau nusivylusi”.

Tyrimas atskleidè, kad daugumai studentu yra labai svarbus grịžtamasis ryšys studijų procese: „mums svarbu žinoti savo klaidas”, ,parašiau darbą atidaviau, nesupratau ką padariau ne taip ir dabar dar nežinau...". Studentai ivvertinti žemesniu balu nei tikèjosi ir negavę paaiškinimo iš dèstytojo apie atliktas klaidas, negali suprasti savo darbo vertinimo „negaunam grižtamojo ryšio, negalime suvokti ìvertinimo".

Tyrimu siekème išsiaiškinti, ar pasitaiko nesąžiningumo atvejų atliekant savarankiškus darbus? Daugiau nei dešimtadalis (13,8 proc.) studentų nurode, kad pasitaikè atvejų, kai savarankiški darbai buvo atliekami nesąžiningai. Tyrimo duomenimis, nedidelé dalis ( 2,1 proc.) pirmakursių $(\mathrm{N}=82)$ pažymėjo, kad savarankiškus darbus dažnai atlieka nesąžiningai (2 pav.).

Anot trečiakursių nesąžiningai atlikti savarankiški darbai „teikia mažai naudos, nes būna copy/paste“. Iš keleto pirmakursių atsakymų galima daryti prielaidą, kad studentai nesąžiningai naudoja literatūros šaltinių ,prirašymą“: „, nesuprantu kam tų knygų turi būti daug, vis tiek rašai iš vienos, o kitus šaltinius sukuri“. Nedidelè dalis (16,6 proc.) studentų trečiakursių, dalyvavusių diskusijoje, prisipažino, jog pirko savarankiškus darbus 1 kurse, nes ,spaudè laikas, nebuvo dėstytojų paramos", ,nemateme praktinès naudos ", ,nemokejome padaryti tai pirkom”.

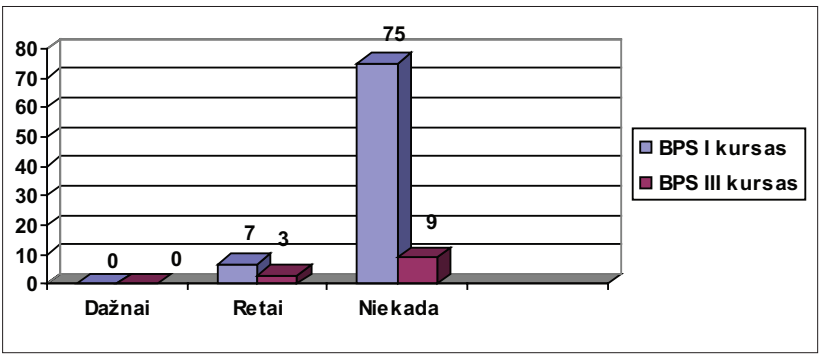

3 pav. Bendrosios praktikos slaugos studijų programos studentų naudojimasis studijų vietoje esamomis internetinèmis erdvėmis savarankiško darbo rašymui 
Tačiau visi trečiakursiai teigè, kad „trečiame kurse studentai darbų neperka, juos daro patys".

Tyrimu siekėme atskleisti organizacinius savarankiškų darbų atlikimo aspektus: dėstytojo, studento ir mokymosi institucijos požiūriu. Nustatyta, kad dažniausiai savarankiško darbo užduotis dèstytojai pateikia iš karto prasidejus ciklui. Pirmakursiai literatūrą pradeda rinkti iš karto dèstytojui pateikus savarankiško darbo užduotis, tačiau teksto surinkimas, pristatymo rengimas paliekamas paskutinei savaitei. Trečiakursiai savarankišką darbą dažniausiai pradeda rašyti likus ménesiui iki savarankiško darbo pristatymo termino, ir tik viena trečiakursė pažymèjo, kad darbą pradeda likus savaitei ar kelioms dienoms iki savarankiško darbo pateikimo termino bei viena trečiakursè teigè savarankišką darbą atlieka iš karto gavus užduotị.

Tyrimo metu buvo svarbu išanalizuoti studentų požiūrị apie bibliotekos paslaugas: didesnè dalis $(84,1$ proc.) pirmo kurso studentų biblioteka yra patenkinti, tačiau mieliau skaito ir naudojasi internetu namuose. Apibendrinus trečio kurso studentų pasisakymus, galima daryti prielaidą, kad dažniausiai studentai biblioteka naudojasi dėstytojų nurodymu, o ne patys siekdami daugiau sužinoti: „savo noru niekas neskaito, tik savarankiškiems darbams, o mokymosi tikslu retai, <..> internetu patogiau...”. Visi trečio kurso studentai teigè, kad „nemokame naudotis duomenų bazèmis bibliotekoje, galètų padèti kas nors, būtų žmogus, kuris parodytų, o gal tai galètų daryti ir informatikos dèstytoja". Tyrimas atskleidè, kad studijų vietoje esančiomis internetinėmis erdvėmis savarankiško darbo rašymui studentai naudojasi retai (3 pav.).

Kadangi didesnę dali grupinių savarankiškų darbų studentai atlieka namuose, galima daryti prielaidą, kad atlikdami grupinius darbus studentai mažai komunikuoja tarpusavyje tiesiogiai.

\section{Išvados}

1. Tyrimas atskleidè edukacinius aspektus, motyvuojančius studentus aktyviai ịsitraukti ị savarankiškų darbų rengimą: savarankiško darbo sąsajos su būsima profesija, parama studentui visuose savarankiškų darbų atlikimo etapuose, savarankiškų darbų užduočių integracija tarpdisciplininiu požiūriu, pagalba pasirenkant savarankiško darbo temą, lankstus dėstytojo požiūris ị savarankiško darbo temos, grupès pasirinkimą, grị̌tamojo ryšio suteikimas. Svarbūs aspektai, skatinantys studentų nesąžiningumą pirmame kurse, neatsakingai bei neapgalvotai dèstytojo pateikta užduotis, nepateiktos užduoties atlikimo gairès, paramos studentui stoka.
2. Tyrimo duomenimis, tik nedidelè dalis studentų savarankišką darbą rašyti pradeda iš karto dèstytojui pateikus užduotį, didžioji dalis pirmakursių savarankišką darbą atlieka paskutinę savaitę, dauguma studentų atlikdami savarankiškus darbus nesinaudoja internetinemis erdvėmis, esančiomis mokymo ịstaigoje, mažai komunikuoja tarpusavyje tiesiogiai, rašydami grupinius savarankiškus darbus. Studentams reikalinga bibliotekos darbuotojų ir/ar informatikos dèstytojo pagalba naudojantis duomenų bazėmis. Apibendrinus tyrimo duomenis galima daryti prielaidą, kad studentai atlikdami savarankišką darbą susiduria su bendradarbiavimo stoka. Dėstytojai, paskyrę savarankišką darbą, studijų eigoje turètų dažniau aptarti savarankiško darbo atlikimo eigą, komunikuoti su studentu, studentų grupèmis, atliekant grupinị savarankišką darbą, spręsti studentams aktualius klausimus.

\section{Literatūra}

1. Bill Meyer, Naomi Haywood, Darshan Sachdev, Sally Faraday. Independent learning: Literature review 2008.

2. Bubnys R., Reflektyvaus mokymo(si) metodų diegimo aukštojoje mokykloje metodika: refleksija, kaip besimokančiųjų asmeninès ir profesinès raidos didaktinis metodas, 2012.

3. Budrienė S., Gefenas V. Studento darbo krūvio ịvertinimas, 2011.

4. Bulavienė D, Jurkšaitienè N. Metodiniai patarimai savarankiškiems darbams rengti, 2010.

5. Daniel Willingham. Jeff Karpicke. The results on the study strategies of students at Washington University in St. Louis. 2009. Prieiga per internetą. http://www.danielwillingham. com/1/post/2012/03/students-should-be-taught-how-to-study. html Žiūrèta: 2014-01-08

6. Marcinkevičienė V., Mikalauskienė B., Liutkevičienė M. Filosofijos dalyko savarankiško darbo efektyvumas ir nauda technologinès krypties studijų programoms, 2010.

7. Markevičienė R., Račkauskas A. ECTS - Europos kreditų kaupimo ir perkèlimo sistema. Istorija. Diegimas. Problemos, 2011.

8. Pečiūrienė A., Radlinskaitė R., Žvinakevičienė D. Savarankiškas darbas profesinio bakalauro studijų procese, 2010.

9. Research for Teachers. Raising achievement through group work. Prieiga per internetą. http://www.tla.ac.uk/site/SiteAssets/RfT1/06RE034\% 20Raising\% 20achievement Žiūrèta: 2014-01-09

10. Self- study Guide, Commission on Institutions of Higer Educational, England Association of Schools and Colleges, Revised, 2013, http: //cihe.eosc.org. Žiūrèta: 2014-01-09

11. Žiliukas P., Lepaitė D.Studijų krypčių aprašų skirtingoms pakopoms kūrimo metodika, Studijų kokybès vertinimo centras, 2012.

12. Žydžiūnaitė V., Teresevičienė M., Gedvilienė G., Klimavičienė I. Savarankiškas mokymasis aukštojoje mokykloje: dèstytojų patirtys, 2013. 


\section{THE ASSUMPTIONS OF ACTIVELY INVOLVING GENERAL PRACTICE NURSING STUDENTS IN SELF- DEPENDENT WORK PREPARATION}

\section{Smaidžiūnienė, V. Rastenienė}

Key words: self-dependent work, nursing studies, educational and organizational self-dependent work making.

\section{Summary}

The main problem of learning institutions that prepare future nursing specialists is to prepare specialists who will get high qualification that correspond to European Union and the country's job market needs. The goal of modern education process is the ability to look for attainment, to know how to use, estimate, judge and organize the gained knowledge and to be able to use it in practice. The aim of this assay is to reveal the approach of general practice nursing students to self-dependent work, its educational and organizational aspects and also to show the elements that make students get involved in organizing self-dependent work in order to gain the professional knowledge that is necessary in practice. The assay revealed the educational aspects that motivate students to get involved in organizing self-dependent work actively: self-dependent work that involves getting knowledge for future profession, sustentation for student, interdisciplinary integration of self-dependent tasks, assistance in choosing the subject of selfdependentent project, flexible lecturer's approach to self-dependent project subjects, choice of groups, giving the reversionary ligament. During the studying process lecturers should pay more attention to the course of self-dependent work, communication with student and student groups, collaborate when solving the problems that are common for students.

Correspondence to: dale.smaidziuniene@go.kauko.lt

Gauta 2014-08-26 